\title{
Article \\ Policing the Borders of the 'Centaur State': Deportation, Detention, and Neoliberal Transformation Processes-The Case of Austria
}

\author{
Kenneth Horvath \\ University of Education Karlsruhe, Bismarckstraße 10, 76133 Karlsruhe, Germany; E-Mail: horvath@ph-karlsruhe.de; \\ Tel.: +49-721-925-4889
}

Submitted: 1 March 2014 | In Revised Form: 29 May 2014 | Accepted: 3 June 2014 | Published: 17 September 2014

\begin{abstract}
Excessive policing of borders and mobilities is one of the key features of current migration regimes in the global North and West. Using Austria as example, this article examines some of the links between the recent development of deportation policies and broad societal transformations - namely neoliberal restructuring. The main argument is that the new model of policing borders and mobilities can be meaningfully characterised as neoliberal in three respects: (i) its structure corresponds to a neoliberal political rationality, (ii) it is functional for current politico-economic relations, and (iii) it is promoted by the very social relations it contributes to. The paper builds on recent studies of how deportation regimes structure labour relations, but moves the focus from the economic function to the form and formation of deportation policies. Concerning the form of regulation, a comparison of current legal frameworks with those of the ColdWar era unveils some crucial features of newly emergent border regimes. First, policing has been massively extended and intensified; second, the criteria for differentiating the vulnerability to policing have grown in number and complexity; third, it is more and more mobility itself that is being policed; and, finally, the punitive turn affects mainly the margins of current global mobility, while the top and center enjoy increased security of residence and mobility rights. Regarding the formation of these new deportation policies, this article uses salient shifts in political discourse as a starting point to illustrate the complexity and context-dependency of the political processes involved.
\end{abstract}

\section{Keywords}

asylum; deportation; labour migration; neoliberalism; precarisation; societal transformation

\section{Issue}

This article is part of the special issue "Policing Ethnicity: Between the Rhetoric of Inclusion and the Practices and Policies of Exclusion", edited by Professor Abby Peterson (University of Gothenburg, Sweden) and Professor Malin Åkerström (University of Lund, Sweden).

(C) 2014 by the author; licensee Cogitatio (Lisbon, Portugal). This article is licensed under a Creative Commons Attribution 4.0 International License (CC BY).

\section{Introduction}

This article examines the turn towards increasingly harsh forms of policing borders and mobilities against the background of changing political-economic constellations. Using the Austrian migration regime as example, I argue that these newly emergent regimes should be understood as integral element of neoliberal transformation: their structure corresponds to what Wacquant has termed the 'neoliberal Centaur state'-liberal at the top, punitive at the bottom (Wacquant, 2009); they fulfill important economic functions; and their emer- gence is enabled by the very societal transformations to which they contribute.

Recent research has pointed to how deportation and detention policies have triggered precarious labour relations. This article builds on these analyses (discussed in Section 2), but moves the focus from the socio-economic function of deportation regimes to the forms of political regulation and the political dynamics involved in their formation. I argue that the current regime can be meaningfully characterised as 'neoliberal' in all these regards. The concept of 'neoliberalism' as it is used in this article is presented in Section 3. 
The epochal change under way in the field of border policing is best captured in comparison with former periods. Therefore, the empirical discussion of the new forms of regulation starts with a comparison of current legal frameworks with policies of the Cold-War era. The post-WWII model is distinctly different from today's constellation in a number of respects. Among others, the new regime operates with far more differentiating criteria and increasingly polices mobility itself. One of the crucial, but hardly discussed features of the new regime is that it allows to promote freedom of mobility at the top while producing extreme forms of exclusion and forced immobilisation at the bottom. The concluding part of Section 5 briefly discusses how politicoeconomic shifts have allowed to establish such a differentiated political framework. I concentrate on developments on the level of political discourse-the securitisation of migration and the linking of deportation and asylum issues - to illustrate how the political processes involved are themselves complexly structured by ongoing societal transformations. In the concluding discussion, I argue that further research should focus on the variegated forms in which neoliberal political projects materialise in given contexts, i.e. on the processes of formation of neoliberal border regimes.

\section{Deportation Regimes and Changing Orders of Social Exclusion}

The excessive policing of borders and mobilities is among the salient features of current migration regimes in the global North and West (De Genova \& Peutz, 2010; Anderson, Gibney, \& Paoletti, 2013). Among the features of these 'deportation machines' (Fekete, 2005) that have received scholarly attention over the past years are the political instruments and the processes of policy development involved (Bloch \& Schuster, 2005), the human rights violations effected by new control policies (Fekete, 2005), the relations between deportation and the constitution of citizenship (Walters, 2010; Anderson, Gibney, \& Paoletti, 2011), and the emergence of new border zones, especially in and around the European Union (Karakayali \& Rigo, 2010).

Mirroring developments in political discourse, these scholarly contributions concentrate on forced and undocumented migration. Recently, however, the analytic focus has moved to the question of how new forms of border policing are linked to labour migration as well as to patterns of social inequalities in general. The emphasis of these recent studies is on how deportation and detention policies contribute to the precarisation of (migrant) workers and thus to the production of a disposable and cheap workforce.

De Giorgi (2010) argues that the current punitive turn in Western migration regimes leads to the increased socio-economic marginalisation of (migrant) workers on a global scale. Comparing current deporta- tion and detention practices to control policies during the transition from feudalism to capitalism, he argues that what we are witnessing is the establishment of a 'global regime of less eligibility'-the forced immobilisation of populations of the global South due to inhibiting costs and risks of moving to the North and West.

Anderson (2010) uses developments in the British labour market to show how immigration controls contribute to the precarisation of labour relations in receiving labour markets. She argues that control policies do not only work as tap to turn migration flows on or off, but effectively create 'hyperflexible labour, working under many types of arrangements (not always "employment"), available when required, undemanding when not' (Anderson, 2010, p. 300). De Genova (2002) uses the notion of deportability to capture how this condition of insecurity is produced by the permanent threat of deportation. The 'disposability of ever deportable migrant labor' (De Genova \& Peutz, 2010, p. 9) is an important element of new global regimes of production. Undocumented migrants mark the extreme of this development (Ahmad, 2008), but deportability permeates labour markets - there are shades of insecurity and precarisation linked to the policing of borders and mobilities.

These studies point to the function deportation policies fulfill for current global politico-economic orders. My analysis builds on these contributions, but shifts the discussion to the form of political regulations and the processes of their formation. The aim is to further our understanding of how deportation and detention policies are embedded in ongoing societal transformations. Borrowing from Braudel, the historical scale of this endeavour is not on the level of the évènement (short-term developments and events in deportation politics) or of the longue durée (the general role of deportation in capitalist nation-states), but on the level of the conjuncture (Lee, 2012): the concrete forms deportation regimes take in period-specific political-economic constellations (cf. Jessop, 2002). Therefore, the discussion of the Austrian case will be organised around a comparison of the current configuration with the postWWII period. The concept of 'neoliberalism' offers an adequate framework for making sense of the ruptures and continuities between these two phases. The following section presents this concept as it is understood in this article.

\section{Neoliberalism as Analytical Framework}

This article shares an understanding that sees neoliberalism primarily as a political project. Following Foucault (Foucault, 2007, 2008), neoliberalism is, in the first place, understood as a political rationality that leads to specific forms of problematising social phenomena and suggests specific forms of dealing with them. The political rationality of neoliberalism is organised around the 
concepts of market and competition. In contrast to classical liberalism, neoliberal thought proclaims (i) that the market and competition need to be actively produced and secured by the state and (ii) that the state itself should be organised according to market principles.

The general neoliberal principle is to govern as little as possible. Governmental interventions are refused not on moral but on utilitarian grounds, not because they are wrong but because they are not useful. The main governmental task is to produce and secure free market exchange without distorting it. Neoliberal government, therefore, mainly manipulates the conditions of free market agency, without intervening directly. Cost-benefit calculations and security considerations are the main modes of policy making, other political logics (e.g. humanitarian reasonings) move to the back.

Sharing Foucault's understanding of neoliberal thought, other authors have moved the focus from the political rationality of neoliberalism to the political projects it organises (Harvey, 2005; Jessop, 2013). As a political project, neoliberalism entails a set of typical measures (deregulation, privatisation, monetarism, workfare rather than welfare...) and leads to the reorganisation of social relations (with precarisation and social polarisation being among the central phenomena). However, the neoliberal project does not take the same form in every context (Brenner, Peck, \& Theodore, 2012). Jessop (2013) identifies four distinct types: the radical Anglo-Saxon variant commonly referred to as Thatcherism and Reaganomics, the mostly also extreme forms of neoliberal transformation in the post-Soviet world, externally enforced programmes of structural adjustment in the global South, and more tempered and partial versions especially in Central and Western European countries such as Germany and Austria.

Understood in this way, neoliberalism is a useful scheme to characterise and analyse the development of new border policies. It links the discussion of political developments to the ongoing societal transformation from Keynesian Fordism to post-Fordist globalisation. And it provides a basis to understand the simultaneity of punitive deportation politics and policies of increasing freedom of mobility that mark current migration regimes.

The link between neoliberalism and punitive policies may seem counterintuitive at first glance. After all, the central aim of neoliberalism is believed to be to diminish the state and increase individual freedom. A number of authors have, however, diagnosed structural links between neoliberal transformation and the rise of penal states (e.g. De Giorgi, 2010). The general line of argument is that the simultaneous reduction of welfare policies and increasing precarisation of poorer parts of the population require punitive countermeasures in order to secure public order and property rights. Wacquant's notion of the Centaur state aims at this double-faced character of neoliberal policies: the neoliberal state promotes freedom and security at the top and fosters punishment and insecurity at the bottom (Wacquant, 2009).

Whether the link between neoliberalism and punitive policies is a necessary one has been the matter of some debate. For example, neoliberal reforms in African nation-states are often neither connected to workfare policies nor to the rise of a penal state (Hilgers, 2012). Though crucial for our general understanding of neoliberal restructuring, this discussion is less relevant for the following analysis. In the concrete Western European context-post-Keynes, post-Fordist, postguestwork-the general pattern of retreating welfare and increasing punitive policies is largely undisputed.

\section{Methodological Notes}

Perhaps due to the complexity of the developments involved, most studies on recent deportation and detention policies focus on single case countries, the UK and the US being the most popular examples (e.g. Anderson, Gibney, \& Paoletti, 2013; Bloch \& Schuster, 2005). The main drawbacks of this strategy are that we cannot take developments beyond the nation-state level into account and that we cannot compare the relative relevance of single factors as would be possible in a multicase design. On the other side, the focus on a single case allows for a more profound analysis over timeand this diachronic perspective defines the main dimension of comparison for this text. The nation-state level has the further advantage of offering comprehensive material for analysing the development of legislative frameworks and political discourses over time. Therefore, this article also focuses on a single case country: Austria. A number of factors make Austria a very interesting example for the context of this article, both regarding its migration regime and its politicaleconomic configuration.

With regards to the political-economic configuration and, more specifically, the implementation of neoliberal policies, Austria corresponds to the pattern described by Jessop (2013) as typical for 'Rheinian capitalism': the tempered and selective adoption of neoliberal policies ${ }^{1}$. Concerning its migration regime, Austria has gone through the same post-WWII phases of guestworker recruitment (Castles \& Kosack, 1973; Wimmer, 1986), emergence of new ethnic minorities (Castles, Booth \& Wallace, 1984), and profound re-

\footnotetext{
${ }^{1} \mathrm{~A}$ recent example shows the ambiguity of neoliberal reform agendas in such a setting. In 2013, the Austrian Ministry of Science was abolished. Science, research, and technology issues are now covered by the Ministry of Economics. This move does not correspond well to the idea of "unideological", evidence-based policy-making or to the self-imagination of a knowledge society. On the other hand, the measure mirrors austerity principles and the extension of market rule to diverse policy areas.
} 
organisation (Messina, 2007; Kraler, 2011) as most Western European countries. The general architecture of the Austrian migration regime is similar to the German one; Castles (1995) subsumes both countries under the category of differential exclusionary regimes, characterised by restrictive citizenship policies, an ethnic understanding of national belonging, and strong marginalisation of migrant workers (Sainsbury, 2006). At the same time, some analytically relevant aspects are more pronounced than in other countries, above all the presence of an extreme-rightwing populist party with broad electoral support (the Freedom Party, FPÖ) and Austria's geopolitical position at the former Iron Curtain.

The findings presented in the following build on research done for my PhD (Horvath 2014a; 2014b). Two kinds of data on the Austrian deportation regime are used. First, a comprehensive overview of the development of the legal framework (legal regulations, amendments...) is used to discuss how the form of political regulation has evolved against the background of changing migration patterns and political-economic contexts (Sections 5.1 and 5.2). Second, a corpus of more than 3,000 parliamentary documents dealing with migration issues was collected. For my PhD, this corpus was analysed both quantitatively and qualitatively, combining a dictionary approach and lexicometric methods with interpretive analyses of the argumentative logics structuring the political problematisation of migration. The quantitative and the qualitative analyses can be seen as complementary and, by and large, converge. For the context of this article, some (mostly quantitative) findings are presented to illustrate the complex processes involved in the formation of a neoliberal deportation regime in Austria (Section 5.3).

\section{The Becoming of a Neoliberal Deportation State}

We can roughly distinguish two phases in the development of the Austrian migration regime after WWII: the guestworker epoch and the post-1989 period. There are overlaps and continuities as well as ruptures and discontinuities between these phases. The periodisation nonetheless allows for systematic comparisons between different constellations of politico-economic contexts, migration practices, labour market relations, and the policing of borders. I first discuss the Austrian deportation regime during the post-WWII era, then give an overview of the measures taken after 1989, and finally briefly discuss how the emergence of punitive deportation policies was itself linked to neoliberal restructuring.

\subsection{Deportation and Detention in the Austrian Guestworker Regime}

Migration patterns to Austria after WWII correspond to those in other Western European countries. Migration from the semi-periphery of the world economy into lower segments of the labour market (Gächter, 1992; Parnreiter, 1994) and the emergence of new ethnic minorities (Castles, Booth, \& Wallace, 1984) are the crucial features of this development. The Austrian guestworker regime drew mainly on Yugoslavian and Turkish labour resources. Migrant labour was overwhelmingly used in industrial mass production which was backed by Fordist-Keynesian welfare policies (Wimmer, 1986; Gächter, 1992). The political context was marked by conservative corporatism and strong 'social partnership' on the one hand and the Cold War on the other (Bauböck, 1996).

As elsewhere, deportation and detention were no salient issues during this period. Anderson, Gibney and Paoletti (2011) argue that-due to their difficulty and unpopularity-deportation policies were only applied in cases of criminal conviction. Nonetheless, deportation and detention did exist as political technologiesbut they differed in important regards from the constellation we see today.

First, the whole migration regime was marked by the Cold War and Austria's self-presentation as humanitarian toehold to the West. In 1954, the not-yetindependent Austrian government abolished the general need for a residence permit. Foreign citizens were thus generally allowed to stay on Austrian territory, unless state authorities had reason to explicitly prohibit their entry or residence. The rhetoric formula was in dubito pro humanitate, and this was, on the surface, interpreted liberally. Missing educational opportunities, economic disadvantage, or a lack of artistic freedom were considered legitimate causes for asylum (Volf, 1995; Heiss \& Rathkolb, 1995). Of course, these symbolic politics were an easy game to play, since the borders were strictly controlled from the other side and most refugees considered Austria only as a transit country (Stanek, 1985). In political discourse, border policing appeared almost exclusively in connection with construals of ideological dangers. Potential spies and intellectuals were the key adversaries.

In spite of its low political salience, deportation did happen. More importantly, it could happen. Deportation had been established in Austria as a political technology back in the 1860s (parallel to social relief policies, cf. Walters, 2010). After WWII, the political instruments were well developed and established, we just know little about how (often) they were put to use. In other words, deportation was present, even if mainly as a possibility.

This leads to the second point: In practice, the resulting deportability was mostly tied to labour migration, not asylum politics. In fact, deportation and labour relations were linked rather directly in legal and administrative regulations. Loss of employment was one of the central grounds for forced expulsion, and some of the sector-specific guestworker agreements included provisions regarding who had to bear the 
costs of a possible forced return. Labour market authorities and social partners were not only key players in migration politics in general (Bauböck, 1996; Wollner, 1996), but also directly involved in the business of forced removal. In practice, deportation might have mainly been applied in cases of criminal conviction-as argued by Anderson et al. (2011) - but as a permanent threat it constituted a specific regime of deportability that was directly linked to labour market developments.

Thirdly, deportation was a rather crude technology compared to today's regimes. The main criterion for security of residence-or, in turn, for being faced with the possibility of deportation-was nationality. This arrangement corresponded to the Fordist national welfare regime. The main dividing line was between migrant and national labour, conforming to the patterns of labour market segmentation (Gächter, 1992; Parnreiter, 1994). Nationality as a criterion was not contested, and there was no apparent need for a more sophisticated system of differentiation. This configuration was first actively challenged by migrants themselves. Former guestworkers successfully went through all legal instances to achieve that their length of residence and their family situation be considered grounds for security of residence-thus introducing new differentiating criteria (Kraler, 2011; Horvath, 2014a). This was only a soft prelude to the changes that were to come.

\subsection{Policing of Borders and Mobilities in Austria After 1989}

From 1991 to 1999 , more than 85,000 migrants were forcefully expelled from Austria-around 26 deportations a day (Winkler, 2011, pp. 4-5). The aim of this subsection is to give a rough overview of the changes to the regulatory frameworks of the Austrian migration regime after 1989 that allowed for this massive number of deportations. I will first discuss the measures and amendments in detail before linking them to the article's main theme-neoliberal restructuring. Due to the complexity and speed of these developments the depiction will necessarily remain incomplete (for a comprehensive discussion see Horvath 2014a).

After the fall of the Iron Curtain, the Austrian border regime was thoroughly reorganised. Table 1 gives a few examples of the measures taken in three areas: labour migration, deportation policies, and general integration policies. These policy areas need to be understood in their interplay. The table shows, first, the dynamisation of migration politics over the past decades. Second, it clearly mirrors the post-1989 punitive turn. Among others, all five aspects identified by Bloch and Schuster (2005) as crucial elements of current forms of policing borders and mobilities have been either introduced or expanded: deportation, detention, incarceration, zoning, and dispersal policies.

One of the first measures was the reintroduction of the residence permit that had been abolished in 1954 . This step may seem negligible, but it turns the logic of legitimating entry and residence around. No longer does the state need reasons to end a migrant's stay in the country, but the migrant herself needs to justify her residence and becomes self-responsible for retaining a legal status. This turn in the logic of forbidding/allowing was a prerequisite for what followed: an abundance of different entry and residence statuses linked to numerous routes into illegalisation.

From the beginning, the upscaling of deportation was one of the key elements of this development. In part, this happened by criminalising certain practices. For example, trafficking and bogus marriage were first declared major administrative and later criminal offenses. In addition, non-compliance with administrative procedures became a possible reason for expulsion. Undocumented entry or the loss of one's residence status can today lead to forced removal. At the same time, removal procedures have been accelerated and the possibilities to legally challenge decisions of deportation authorities have been severely limited.

Similar developments are evident for detention and incarceration. The possible duration of detention has been extended to a maximum of ten months (within every 18 month period), up from two months in the post-WWII decades. Reasons for detention nowadays include smaller offenses and non-compliance with administrative rules. Conditions during detention have been made even harsher. Many measures stand in obvious conflict to common understandings of human and fundamental rights (Fekete, 2005). Children can now be separated from their parents and detainees on hunger-strike can in principle be force-fed. Migrants can today be detained without any offense-even without any identifiable construed threat.

Deportation and detention measures were combined with dispersal and zoning techniques. Today, asylum seekers are kept in reception camps at the beginning of the asylum procedure. They are then dispersed across the country, sometimes to remote areas, and (i) obliged to report regularly to the authorities and (ii) allowed to travel only in the area of their residence. Failing to follow these rules may have serious repercussions for their status or asylum application.

A number of features of the new constellation stand out in comparison to the Fordist constellation. First, it is increasingly mobility itself that is being policed-not criminal behaviour or alleged threats to social security. This is achieved by emphasising compliance with established rules. Depending on their migration channel, migrants may have to follow regulations from before their travel to Austria starts (including passing language tests), and any failure to do so may result in illegalisation and possible expulsion. This turn to policing mobility itself goes hand in hand with a change in the construed threats that presumably justify 
deportation measures. In contrast to the personified ideological dangers of the Cold War era, current threats are imagined as mobile and fluid networks, of- ten linked to criminal activities and sometimes potential terrorism (Waever, Buzan, \& de Wilde, 1993; Huysmans, 2006).

Table 1. Selection of changes to the Austrian migration regime over time.

\begin{tabular}{|c|c|c|}
\hline Year & Labour migration & $\begin{array}{l}\text { Policing, deportation, and } \\
\text { detention }\end{array}$ \\
\hline 2011 & $\begin{array}{l}\text { RWR-Card, permant seasonal } \\
\text { worker status }\end{array}$ & $\begin{array}{l}\text { "Compulsory attendance" for } \\
\text { asylum seekers, detention possik } \\
\text { up to } 10 \text { months, separation of } \\
\text { children from parents during } \\
\text { detention }\end{array}$ \\
\hline 2009 & & $\begin{array}{l}\text { Zoning measures, reporting } \\
\text { obligation, time for appeal reduc } \\
\text { to one week, "subsequent asylur } \\
\text { applications" abolished,... }\end{array}$ \\
\hline 2005 & $\begin{array}{l}\text { Visum requirement for seasonal } \\
\text { workers abolished }\end{array}$ & $\begin{array}{l}\text { Reasons and possible duration o } \\
\text { detention extended, forced feed } \\
\text { of detainees on hunger strike,... }\end{array}$ \\
\hline 2003 & & $\begin{array}{l}\text { Screening system at reception } \\
\text { centre, abolition of suspensive } \\
\text { effect of appeals against asylum } \\
\text { decisions }\end{array}$ \\
\hline
\end{tabular}

2002 Simplified: seasonal work and high-

skilled migration

2000 Seasonal work extended to all economic sectors, new status of harvest worker

Trafficking becomes criminal offense

1992 Seasonal workers programme and quota system

New 'alien workers law'
Measures against "asylum abuse", ratification Dublin convention

Third country regulation introduced

Re-introduction of residence permit, trafficking (administrative) offense

Length of residence and family life acknowledged as reasons for protection against deportation

Introduction of an own, secure residence status for refugees
"Integration contract" with obligatory language and

"integration" courses

Integration and citizenship

Tightening of language

requirements

Citizenship test, uninterrupted legal residence required for citizenship, tightening of language requirements

Language requirements for citizenship acquisition 
Second, there is a complex differentiation of mobility and residence rights. The mechanisms by which 'privileged' legal statuses are assigned are complex and often indirect. While for some their country of origin suffices, others attain relative security by entering under special quota regulations or the recently established Red-White-Red Card, a points-based system for so-called highly skilled migrants. Once in the country, migrants can step-by-step increase their security of residence provided they have a secure income and comply with legal regulations. If any of these conditions do not apply (not entering with a secure residence/employment permit, losing employment, not obtaining sufficient language skills...), the migrant risks dropping out of this system of interlinked entry-residence-employmentintegration regulations. 'Integration tests' and language requirements are today among the key criteria for securing one's mobility and residence rights; the effects of these requirements are not the same for different 'kinds' of migrants: those employed in ethnicised labour market segments or lacking formal education are relatively disadvantaged.

Third, the relation between deportation and labour migration has become more indirect. The status of seasonal worker introduced in 1992 serves as an example (Horvath, 2014b). Seasonal workers are employed in other economic segments than former guestworkers, mainly construction, agriculture, and tourism (Horvath, 2012). Above all, they are confronted with a far more precarious legal situation. They never obtain any right to settlement, even after years of employment; they do not enjoy unemployment benefits; and they cannot extend their labour market mobility over time. This radical precarisation was achieved by a minor passage in the Residence Law. The deportability of guestworkers was in the first place defined in the Alien Workers Law and only backed by general regulations on entry and residence of aliens, the precarity of seasonal workers is mainly established in general residence provisions and only linked to the work permit system in a second step.

Fourth, deportation has become a highly salient political issue. The relevance of this point for our understanding of the whole process will be discussed in the following subsection.

How are these developments linked to neoliberal transformation processes? Starting from Wacquant's notion of the neoliberal Centaur state, the hierarchical differentiation of deportation policies stands out as a first crucial characteristic of the current regime. At the top, the migration regime ensures and promotes mobility and security of residence. At the bottom, a mobility-related punitive turn results in immobilisation, marginalisation, and precarisation. This first feature leads directly back to the economic function of deportation policies (Anderson, 2010; De Genova \& Peutz, 2010; de Giorgi, 2010). The Austrian seasonal workers scheme is a good example for the kind of deportability-backed precarisation usually discussed in this context. At the same time, the extended freedom of mobility and the increased security of residence at the top also fulfill important functions. They are prerequisites for other forms of mobility linked to international investment and trading and the establishment of a regime of transnational elite mobility.

Further and corresponding to the principle of selfreliance and workfare, the punitive deportation policies at the bottom of the mobility hierarchy fulfill social control functions and have strong disciplining effects by punishing non-compliance with rules, making migrants themselves responsible for managing the complex interplay of employment and residence policies, and establishing the permanent threat of increased deportability to those who do not enjoy comparably favourable mobility and residence rights.

The shift towards less direct intervention in labour relations-establishing deportability in other than directly labour-market related regulations-mirrors the idea of not intervening directly in the free market exchange of individuals. Instead, governmental activity concentrates on manipulating the background conditions of market agency. Following De Giorgi (2010), we may interpret the direct policing of mobility rather than of labour relations as a new form of immobilisation and forced localisation of the very populations that are uprooted by the dynamics of global capitalism-or in Foucault's terms as an instance of biopolitical regulation of populations and their mobility.

In addition, the punitive turn mirrors a general move in the political architecture of the Austrian migration regime that is in line with the neoliberal reshaping of the political arena. Decision-making powers and responsibilities have moved from social partners to the central government, and within the state bureaucracy from the field of social policy to the Ministry for the Interior. This political architecture does not only correspond to neoliberal principles, it also conforms to changing labour market relations which are less and less covered by the post-WWII forms of social partnership.

Current deportation policies do not only prove functional for highly segmented post-Fordist labour markets, their architecture and logic also mirror a neoliberal political agenda. But how can we explain the emergence of these new policies without resorting to a teleological argument (that they are there because they are functional)? What processes have allowed for the formation of the new deportation regime? In the following subsection, I argue that the formation of these policies is itself best understood against the background of neoliberal restructuring. However, the involved processes are heavily context-dependent. The list of factors and actors that structure the concrete formation of neoliberal border regimes includes, among others, political parties and security profession- 
als, welfare institutions and their path-dependencies, labour-market developments, and geo-political constellations. Due to this complexity, the following discussion remains sketchy and aims mainly at laying the ground for further research.

\subsection{Reflections on the Formation of Neoliberal Deportation Policies in Austria}

The establishment of the kind of measures described above is not a trivial affair. They stand in opposition to fundamental principles of liberal market economies (equality and freedom) and thus require legitimisation. In light of the obvious tensions and contradictions, how can we explain the development of such a functional arrangement, if not by some form of teleological or conspiracy-theoretic approach? The following brief discussion offers a few initial reflections. I choose two decisive discursive shifts as a starting point to illustrate how the emergence of neoliberal deportation policies is complexly linked to societal transformations as well as to concrete contexts.

\section{References to crime}

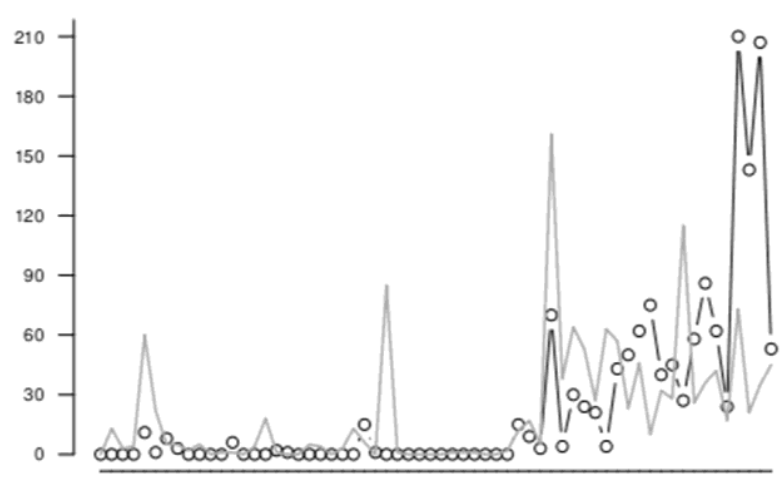

$\begin{array}{lllllllllllll}1946 & 1952 & 1957 & 1962 & 1969 & 1974 & 1979 & 1984 & 1989 & 1994 & 1999 & 2004 & 2009\end{array}$

References to illegality

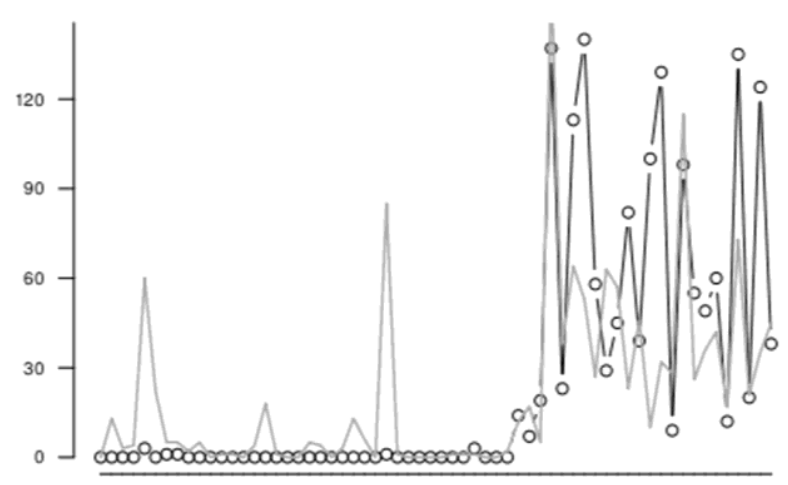

$\begin{array}{lllllllllllll}1946 & 1952 & 1957 & 1962 & 1969 & 1974 & 1979 & 1984 & 1989 & 1994 & 1999 & 2004 & 2009\end{array}$
The first crucial discursive shift is the securitisation of migration over the past decades (Waever et al., 1993; Bigo, 2001, 2002; Huysmans, 2006). From the mid-1980s onwards, migration issues became dramatically politicised throughout Western Europe (Hammar, 2007; Messina, 2007). This politicisation was primarily linked to construals of migration as a threat to public order, cultural identity, and/or social security. Figure 1 illustrates this development.

The second decisive discursive shift is the linking of deportation to asylum issues. After 1989, asylum became the central field in which deportation policies were discussed (and developed). Table 2 shows the factor by which certain indicator terms were over- or underrepresented in parliamentary contributions dealing with asylum before and after 1989. Before 1989, the policy field focused on equality, integration, and labour rights. These egalitarian issues move to the background after 1989, while the formerly underrepresented issues of detention and illegality are now heavily overrepresented.

\section{References to 'integration'}

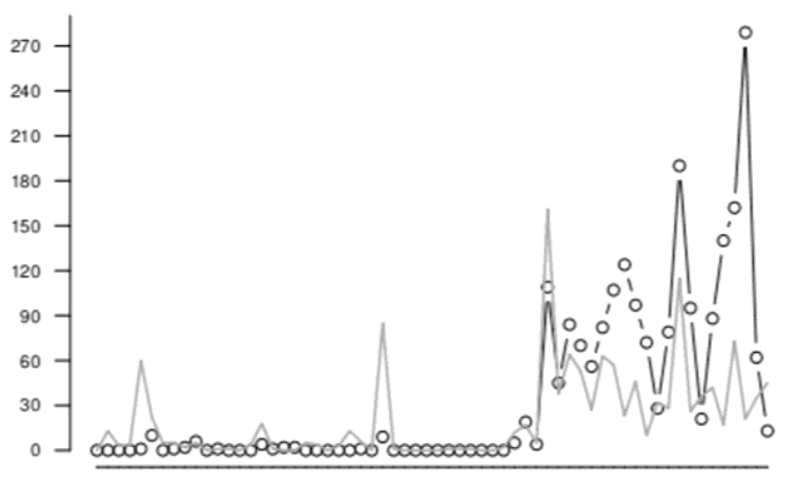

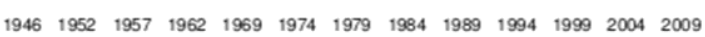

References to labour market

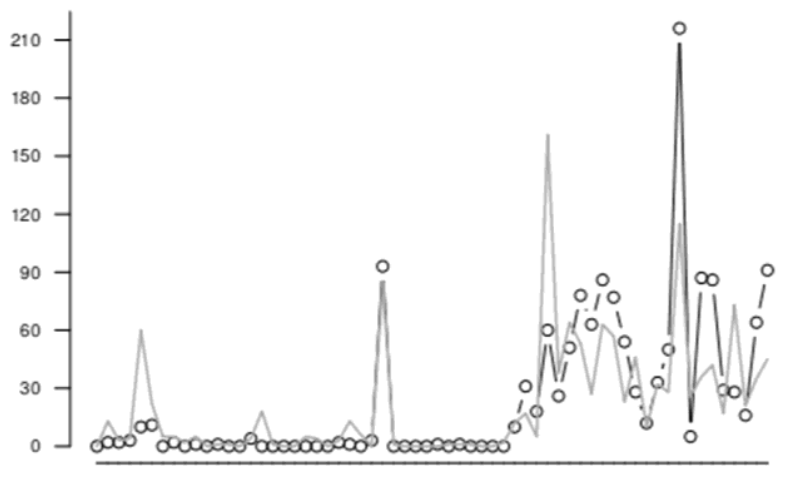

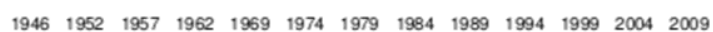

Figure 1. Politicisation and securitisation of migration, 1945-2012; number of references to indicator terms in the Austrian parliament; grey line in each graph: references to "economy". 
Table 2. Re-embedding of asylum issues. The table lists the relative frequency of indicator terms in contributions dealing with asylum as compared to other contributions.

\begin{tabular}{llc}
\hline Year & Term & $\begin{array}{c}\text { Factor of } \\
\text { over-/under- } \\
\text { occurrence }\end{array}$ \\
\hline $1945-$ & equality/equalitisation & 8,74 \\
1989 & integration & 12,23 \\
& labour laws & 7,80 \\
& illegal & 0,27 \\
& detention & 0,24 \\
$1990-$ & equality/equalitisation & 0,14 \\
2011 & integration & 0,59 \\
& labour laws & 0,20 \\
& illegal & 1,04 \\
& detention & 3,06 \\
& detention center & 32,17 \\
\hline
\end{tabular}

A few preliminary reflections on how these two discursive shifts (i) structured the development of neoliberal deportation policies and (ii) were themselves structured by a complex interplay of political, social, and economic processes illustrate how the formation of new border regimes hinges on concrete constellations and contexts.

Concerning its structuring role for the development of new policies, the changed discursive context was a necessary condition for establishing neoliberal deportability in Austria. The establishment of the seasonal worker status in the early 1990s provides an example (Horvath, 2014a, 2014b). The demand for such a status was not new-but for decades it had been opposed for humanitarian as well as socio-political reasons. The securitised context created a window of opportunity for employer organisations who made use of the emergency atmosphere to push their agenda. This was possible because the new status could be interpreted as a security measure (and hence part of the new deportation regime) itself-it promised to bring practices of labour mobility under state control that had existed in Austrian border regions for decades, but mostly in undocumented forms (Horvath, 2012). Construed existential threats served as pretext for 'exceptional' political measures. A number of other measures that had been planned for years were pushed through in a similar vein, partly bypassing normal parliamentary procedures.

Linking deportation and detention to the ambiguous, symbolically charged, and contested concepts of 'asylum' and 'refugee' further facilitated the adaptation of the regularity framework. Actual deportation practices still concern mainly migrants with other than asylum-related legal titles (Winkler, 2011). Discursively decoupling them from labour migration shifted public attention away from how migrants and refugees are affected by them as workers-and hence from how labour market relations and patterns of social exclusion are structured by deportation and detention policies. As a means of directly regulating labour relations, deportation had become highly contested over the 1980s. Only by linking it to the image of floods of bogus asylum seekers and transnational criminal networks was it possible to forge new deportation policies.

The securitisation of migration was not only a necessary condition for adapting the migration regime to changing politico-economic contexts, it was also fostered by these transformations. From the 1980s onwards, increasing social insecurity in combination with a post-guestwork constellation seemed to threaten the established 'order of honour'. This constellation contributed to the rise of the far-right Freedom Party-one of the key players in securitising migration in Austria. In this context, demands for harsh deportation policies were also symbolic politics meant to re-constitute citizenship (Walters, 2010; Anderson et al., 2011). Even though the dominant imagination of the general public as being overwhelmingly opposed to immigration is too simplistic (Lefkofridi \& Horvath, 2012), political parties tended to play the anti-migrant card in this context, thus contributing to the general securitisation of migration. The simultaneous strengthening of the 'right arm of the state' (Wacquant, 2009)-security professionals and penal systems-made alternative, more social policy oriented approaches of dealing with the tensions that resulted from post-Fordist and neoliberal restructuring less likely.

These developments had started well before the 1990s. The described adaptations in the migration and border regime therefore may seem to have been 'overdue'. In the case of Austria, the Cold War had to end before the restructuring of the deportation regime could start. The abruptness of the developments in Austriaboth on the level of political discourse and of legal frameworks-illustrates how the formation of neoliberal projects hinges on local contexts. Before 1989, securitised discussions especially of asylum were untenable for ideological reasons. At the same time, the strategic agency of state institutions was organised in accordance with the geopolitical constellation. For example, security professionals who had been concentrating on Cold-War style spying of enemy states for decades now had to redefine their role and struggle for influence in new areas (Bigo, 2001, 2002). Migration-staged as massive networked mobility closely tied to international crime-was a logical choice. Due to their general strengthening as part of the 'right arm' of the state in comparison to other state actors (itself part of the neoliberal reform agenda), their strategic agency proved highly effective.

To sum up, the combination of these two discursive shifts - the securitisation of migration and the coupling of deportation and asylum-gives a first indication of the complex ways in which the development of neoliberal deportation policies is itself mediated by politicoeconomic shifts, political discourses, geopolitical con- 
stellations, and strategic agency. Discursive developments have played an enabling role in this process, but they are themselves shaped in various ways by the very developments they contribute to.

\section{Conclusion}

I have argued that current deportation regimes can be meaningfully characterised as neoliberal in three regards. First, the form of these policies corresponds to neoliberal principles. Chief among these correspondences is the simultaneity of extended mobility and residence rights at the top and punitive measures at the bottom of the global hierarchy of mobility rights that matches the Centaur-form of the neoliberal state. Second, the effects of the new deportation regime are economically functional for segmented labour markets. Third, the very mechanisms to which deportation contributes - the polarisation of social orders, social exclusion, and social insecurity-promote its further development.

Deportability today works within a system of highly differentiated migration and border regimes - the rather rudimentary differentiation between national and migrant labour that organised the guestworker systems has long given way to a complex hierarchisation of mobility rights. Recent developments in the EU underscore the relevance of enquiring into these developments. Contrary to the mantra of free mobility, we are currently witnessing different forms of making fundamental rights conditional-be it the transitional provisions for members of new EU-member states or the expulsion of EU citizens who do not fit the image of the ever-profitable and self-reliant neoliberal subject. Belgium issued more than 2,700 expulsion letters to EU citizens in 2013 alone, following the example of the French state and its offensive against Roma migrants that was started in 2010.

The picture drawn in this article is, of course, incomplete. Most importantly, the paths that lead to the neoliberalisation of migration politics vary considerably depending on, for example, geopolitical factors or national welfare regimes. More research is needed to develop our understanding of the complex political processes involved, their contested nature as well as their links to social inequalities and existing power relations. Parallels in the general form and functioning of neoliberal border regimes notwithstanding, the Austrian example shows how the formation of theses policies cannot be understood without reference to the concrete constellation of actors, institutions, and structural settings. Recent protest movements of refugees in different countries across Europe may serve as a starting point for reflecting these interdependencies.

\section{Conflict of Interests}

The author declares no conflict of interests.

\section{References}

Ahmad, A. (2008). Dead Men Working: Time and Space in London's (Illegal) Migrant Economy. Work, Employment and Society, 22(2), 301-318.

Anderson, B. (2010). Migration, Immigration Controls and the Fashioning of Precarious Workers. Work, Employment and Society, 24(2), 300-317.

Anderson, B., Gibney, M.J., \& Paoletti, E. (2011). Citizenship, deportation, and boundaries of belonging. Citizenship Studies, 15(5), 547-563.

Anderson, B., Gibney, M., \& Paoletti, E. (2013). The Social, Political and Historical Contours of Deportation. New York, USA: Springer.

Bauböck, R. (1996). Nach Rasse und Sprache verschieden: Migrationspolitik in Österreich von der Monarchie bis heute. IHS Reihe Politikwissenschaft, 31.

Bigo, D. (2001). Migration and Security. In: V. Guiraudon \& C. Joppke (Eds.). Controlling a New Migration World (pp. 121-149). London, UK, New York, USA: Routledge.

Bigo, D. (2002). Security and Immigration: Toward a Critique of the Governmentality of Unease. Alternatives: Global, Local, Political, 27(supplement), 63-92.

Bloch, A., Schuster, L. (2005). At the Extremes of Exclusion: Deportation, Detention and Dispersal. Ethnic and Racial Studies, 28(3), 491-512.

Brenner, N., Peck, J., \& Theodore, N. (2012). Variegated neoliberalization: geographies, modalities, pathways. Global Networks, 10, 182-222.

Castles, S. (1995). How Nation-States Respond to Immigration and Ethnic Diversity. New Community, 21(3), 293-308.

Castles, S., Booth, H., \& Wallace, T. (1984). Here for good: Western Europe's new ethnic minorities. London, UK: Pluto.

Castles, S., Kosack, G. (1973). Immigrant workers and class structure in Western Europe. Oxford, UK: Oxford University Press.

De Genova, N. (2002). Migrant 'Illegality' and Deportability in Everyday Life. Annual Review of Anthropology, 31, 419-447.

De Genova, N., Peutz, N (Eds.) (2010). The Deportation Regime. Sovereignty, Space, and the Freedom of Movement. Durham and London, UK: Duke University Press.

De Giorgi, A. (2010). Immigration control, postFordism, and less eligibility: A materialist critique of the criminalization of immigration across Europe. Punishment \& Society, 12(2), 147-167.

Fekete, L. (2005). The Deportation Machine: Europe, Asylum and Human Rights. Race \& Class, 47(1), 64-91.

Foucault, M. (2007). Security, Territory, Population: Lectures at the Collège de France 1977-1978. Houndmills, UK: Palgrave Macmillan.

Foucault, M. (2008). The Birth of Biopolitics: Lectures at the Collège de France 1978-1979. Houndmills, UK: 
Palgrave Macmillan.

Gächter, A. (1992). (Un)ordentliche Beschäftigungspolitik. In T. Prader (Ed.), Moderne Sklaven. Asyl- und Migrationspolitik in Österreich (pp. 48-69). Vienna, Austria: Promedia.

Hammar, T. (2007). The Politicisation of Immigration. In T. Abbas F. \& Reeves (Eds), Immigration and Race Relations. Sociological Theory and John Rex (pp. 99110). London, UK: I.B. Tauris.

Harvey, D. (2005). A Brief History of Neoliberalism. Oxford, UK: Oxford University Press.

Heiss, G., \& Rathkolb, H. (Eds.) (1995). Asylland wider Willen. Flüchtlinge in Österreich im europäischen Kontext seit 1914. Vienna, Austria: Dachs Verlag.

Hilgers, M. (2012). The historicity of the neoliberal state. Social Anthropology, 20(1), 80-94.

Horvath, K. (2012). National numbers for transnational relations? Challenges of integrating quantitative methods into research on transnational labour market relations. Ethnic and Racial Studies, 35(10), 1741-1757.

Horvath, K. (2014a). Die Logik der Entrechtung. Sicherheits- und Nutzendiskurse im österreichischen Migrationsregime. Göttingen, Germany: Vandenhoeck \& Ruprecht.

Horvath, K. (2014b). Securitisation, economisation and the political constitution of temporary migration: The making of the Austrian seasonal workers scheme. Migration letters, 11(2), 154-170.

Huysmans, J. (2006). The Politics of Insecurity: Fear, Migration and Asylum in the EU. London, UK, and New York, USA: Taylor \& Francis.

Jessop, B. (2002). The Future of the Capitalist State. Cambridge, UK: Polity Press.

Jessop, B. (2013). Putting neoliberalism in its time and place: a response to the debate. Social Anthropology, 21(1), 65-74.

Karakayali, S., \& Rigo, E. (2010). Mapping the European Space of Circulation. In N. De Genova \& N. Peutz (Eds.), The Deportation Regime. Sovereignty, Space, and the Freedom of Movement (pp. 123-145). Durham and London, UK: Duke University Press.

Kraler, A. (2011). The Case of Austria. In G. Zincone, R. Penninx \& M. Borkert (Eds.), Migration Policymaking in Europe. The Dynamics of Actors and Contexts in Past and Present (pp. 21-59). Amsterdam, Netherlands: Amsterdam University Press.
Lee, R. E. (2012). Fernand Braudel, the Longue Durée, and World System Analysis. In I. Wallerstein \& R. E. Lee (Eds.), The Longue Durée and World System Analysis (pp. 1-7). New York, USA: State University of New York Press.

Lefkofridi, Z., \& Horvath, K. (2012). Migration Issues \& Representation in European Liberal Democracies. Representation, 48(1), 29-46.

Messina, A. M. (2007). The Logics and Politics of PostWWII Migration to Western Europe. New York, USA: Cambridge University Press.

Parnreiter, C. (1994). Migration und Arbeitsteilung. Ausländerlnnenbeschäftigung in der Weltwirtschaftskrise. Vienna, Austria: Promedia.

Sainsbury, D. (2006). Immigrants' Social Rights in Comparative Perspective: Welfare Regimes, Forms of Immigration and Immigration Policy Regimes. Journal of European Social Policy, 16(3), 229-244.

Stanek, E. (1985). Verfolgt, verjagt, vertrieben. Flüchtlinge in Österreich. Vienna, Austria: Europaverlag.

Volf, P. P. (1995). Der Politische Flüchtling als Symbol der Zweiten Republik. Zur Asyl- und Flüchtlingspolitik seit 1945. Zeitgeschichte, 11-12, 415-435.

Wacquant, L. (2009). Punishing the Poor. The Neoliberal Governemnt of Social Insecurity. Durham and London, UK: Duke University Press.

Waever, O., Buzan, B., \& de Wilde, J. (Eds.) (1993). Identity, migration and the new security agenda in Europe. London, UK: Pinter.

Walters, W. (2010). Deportation, Expulsion, and the International Police of Aliens. In N. De Genova \& N. Peutz (Eds.). The Deportation Regime. Sovereignty, Space, and the Freedom of Movement (pp. 69-100). Durham and London, UK: Duke University Press.

Wimmer, H. (Ed.) (1986). Ausländische Arbeitskräfte in Österreich. Vienna, Austria: Campus Verlag.

Winkler D. (2011). Das "Fremde" verwalten. Die Praxis zwangsweiser Rückführungen von MigrantInnen in Österreich (MA Thesis). University of Vienna, Austria.

Wollner, E. (1996). Auf dem Weg zur sozialpartnerschaftlich regulierten Ausländerbeschäftigung in Österreich. Die Reform der Ausländerbeschäftigung und der Anwerbung bis Ende der 1960er Jahre (MA thesis). University of Vienna, Austria.

\section{About the Author}

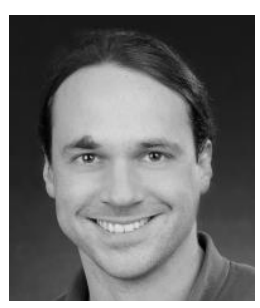

Dr. Kenneth Horvath

Kenneth Horvath holds a PhD in Sociology from the University of Vienna. His main research interests lie in the field of changing migration and citizenship regimes, specifically in the context of the enlarged EU, on the interplay of migration and education regimes, and on methodological challenges in researching current dynamics in global migration patterns and policies. Currently, he holds a postdoctoral position at the Karlsruhe University of Education. 